\title{
THE EFFECT OF GRAPHIC ORGANIZER INSTRUCTION ON STUDENTS' READING MOTIVATION
}

\author{
Syafrizal \\ Islamic University of Indragiri-Tembilahan \\ E-mail: rizaltlp@gmail.com
}

\begin{abstract}
This study aims to find out the effect of graphic organizer instruction on the students' reading motivation. The study was done through a quasi-experimental design. The data were collected using Motivation for Reading Questionnaire (MRQ) developed by Wigfield and Guthrie (1997). The population consisted of 119 students. A cluster sampling technique was used to take them as samples. The samples were divided into two groups; experimental group and control group. Then, the data were analyzed using t-test and paired sample t-test methods to find out whether there was a significant difference between the experimental group taught by graphic organizer instruction as the treatment and the control group taught conventionally. The results of the research show that the significant probabilities were higher than $0.05(>0.05)$ ) in both paired sample t-test and independent sample t-test. It meant that there was a significant difference in the students' reading motivation in the pre-questionnaire and the post-questionnaire of the classes. To sum up, the application of graphic organizer instruction gives a positive effect on the students' reading motivation.
\end{abstract}

Keywords: graphic organizer instruction, reading motivation

\begin{abstract}
Abstrak
Tujuan dari penelitian ini adalah untuk mengetahui pengaruh instruksi grafik organizer terhadap motivasi membaca siswa. Penelitian dilakukan melalui desain kuasi-eksperimental. Data dikumpulkan menggunakan Motivation for Reading Questionnaire (MRQ). Populasi terdiri dari 119 siswa. Teknik cluster sampling digunakan untuk mengambil sampel. Sampel dibagi menjadi dua kelompok; kelompok eksperimen dan kelompok kontrol. Kemudian, data dianalisis dengan menggunakan t-test dan paired sample t-test untuk mengetahui apakah ada perbedaan yang signifikan antara kelompok eksperimen yang diajarkan dengan grafik organizer dan kelompok kontrol yang diajarkan secara konvensional. Hasil penelitian menunjukkan bahwa probabilitas signifikan lebih tinggi dari 0,05 (> 0,05) pada paired sample t-test dan independen t-test. Ini berarti bahwa ada perbedaan yang signifikan pada motivasi membaca siswa dalam pra-kuesioner dan dalam post-kuesioner. Singkatnya, penerapan grafik organizer memberikan efek positif terhadap motivasi membaca siswa.
\end{abstract}

Kata Kunci: Instruksi pengaturan grafik, motivasi membaca siswa 


\section{INTRODUCTION}

Effective teaching reading is crucial to learning English. because the products of good teaching reading instructions is not only the comprehension of the reading material but also students' perceptions toward reading itself. The effectiveness of a teaching reading can be enhanced through the appropriate reading instruction adopted in a learning situation. Reading instruction is a very detailed process that is taught in a variety of ways. Teaching reading strategies is a form of instruction that offers a resource for students to turn to when struggling to read.

One of the instructions that can be used in reading is a graphic organizer. A graphic organizer can be defined as a visual and graphic display that depicts the relationships between facts, terms, and ideas within a learning task. Graphic organizers are also referred to as knowledge maps, concept maps, story maps, cognitive organizers, advance organizers, or concept diagrams (Strangman, Hall, \& Meyer, 2003). Graphic organizers have multiple benefits. These benefits include helping learners grasp the material by assisting in seeing the relationships between ideas, concepts, or authors. Graphic organizers also assist in memory recall.

Graphic organizers encourage the use of developing higher-level thinking skills by assisting students to synthesize and integrate information, ideas, and concepts. Ellis and Howard (2007) stated that graphic organizers are effective across subject areas because they provide visual cues designed to assist students in their understanding of information by organizing information. According to Yin, Vanides, Ruiz-Primo Ayala, and Shavelson (2005), graphic organizers allow students a means of creating connections by visually showing relationships among concepts.

Reading instructions also affect students' motivation. Students who have a reasonable amount of skills to turn to for direction have better attitudes on reading motivation. As reading skills develop, students' attitudes towards 
reading ability improved their selfconcepts as readers (Melekoglu \& Wilkerson). Feeling confident in one's personal ability to read tied closely with one's motivation to be a reader, thus increasing positive attitudes towards reading.

Moreover, Reading instruction has multiple ways to be delivered to students; teaching reading strategies is a huge part of what students need to have positive attitudes towards reading. The strategies help avoid negatively influencing students' attitudes toward reading; therefore influencing their motivation of reading. The instruction supported the students reading for situational purposes overtime and affected their intrinsic motivation to read as well as their overall attitude towards reading.

Many researchers have focused that there are relations between reading instruction and students' attitudes including reading motivation. Therefore, this research investigates the effect of graphic organizer instruction on students reading motivation at senior high school AlRasyid. The hypothesis of this study is stated below and the expected result is the alternative hypothesis (Ha) is accepted:

1. Ho: There is no significant effect of graphic organizer instruction on students' reading motivation at Islamic senior high school AlRasyid

2. Ha: There is a significant effect of graphic organizer instruction on students' reading motivation at Islamic senior high school AlRasyid

\section{Graphic Organizer Instruction}

Graphic organizers are an effective educational tool because they help students organize facts, thoughts, and other comprehension elements such as inferences, predictions, and summaries (Hollowell, 2009). It means that by using graphic organizers the students can effectively arrange the message of the text in their mind so that it is easy to recall it. In addition, graphic organizers are used as the rescuer tool when the readers failed in understanding text. Nikolai (2009) states that graphic organizers can help students understand the relationship among various pieces of 
information that they may have otherwise failed to identify.

In line with Nikolai, Sharrock (2008) states that graphic organizers are visual displays that illustrate the relationship between facts, terms, or ideas. In a text, the sentences relate to one another in constructing meaning, so students need to understand the relationship among the sentences. Moreover, a graphic organizer can become a bridge to connect the whole ideas in the text.

\section{Graphic organizers help} students focus on what is important (Bromley, DeVitis and Modlo, 1995) because they highlight key concepts and vocabulary, and the relationships among them by providing the tools for critical and creative thinking. Moreillon (2007) states that graphic organizers can be developed to help the readers record main ideas and surprising information as well as their connections, responses, and interpretations. Moreover, the students can easily record the ideas when the texts are served through graphic organizers. Besides, graphic organizers are not simply done individually but they can be done in groups.

Jacobson (2007) suggests that graphic organizers are the visual tools allowing students to structure information and to arrange key concepts that can be performed as a whole class, small groups, or individual activities. Fundamentally, both individually and collaboratively graphic organizers can be implemented in teaching reading comprehension.

\section{Reading Motivation}

Motivation refers to the initiation, direction, intensity, and persistence of behavior. It means having the encouragement to do something. A motivated student can be reaching for a long term goal or a more short-term goal. Trying to teach students who seem to have lost interest in learning and are displaying no motivation to learn in school or who are defeated or turned off to school for any number of reasons, is a frustrating and all too common experience for teachers in today's classroom and schools (Deci \& Ryan, 1985). 
It is believed that when students are motivated to perform competently on academic tasks, they will learn by their academic abilities. For this reason, working to enhance students' academic motivation is worthwhile. Academically motivated students tend not to disrupt the instructional environment; they infrequently need to be disciplined; they listen when listening is appropriate because they are interested in what is being said. They discuss when the discussion is appropriate because they want to share their thoughts with others. When students are academically motivated, their teachers often become professionally.

motivated, working hard to provide students with worthwhile educational experiences and finding more satisfaction in doing so (Cheryl, 1992).

The importance of motivation in enhancing second or foreign language learning is undeniable. Lifrieri (2005) points out that when asked about the factors which influence individual levels of success in any activity such as language learning, most people would certainly mention motivation among them. Brown (2001) states that it is easy in second language learning to claim that a learner will be successful with the proper motivation. With similar views, Gardner (2006) posits that students with higher levels of motivation will do better than students with lower levels. He further adds that if one is motivated, he or she has reasons for engaging in the relevant activities, expends effort, persists in the activities, attends to the tasks, shows a desire to achieve the goal, enjoys the activities, etc (Gardner, 2006).

According to Guthrie \& Wigfield (1997). Reading motivation is one's purpose, idea, and desire related to the title, action and the results of the reading. By having motivation the students will be easy to catch the point of a text. They will also have the desire to share and discuss reading material with other friends. Also, the motivated reader is not only about students who are having fun while reading. what is meant by motivation are values, beliefs, and behavior while reading 
for every individual. Moreover, Baker and Wigfield (1999) state that reading is an effortful activity that children often can choose to do or not to do, it also requires motivation. In reading literature, much of the work relevant to readers' motivation has been framed in terms of attitudes toward reading. Reading attitudes typically are defined as readers' effect toward reading (Alexander \& Filler, 1976; Mathewson, 1994; McKenna, Kear, \& Ellsworth, 1995). The motivational consequences of reading attitudes are that children with more positive attitudes are more motivated to read. A substantial body of work also exists in reading interest, defined as either a characteristic of the person or of the text (Renninger, Hidi, \& Krapp, 1992; Schiefele, 1996). Interest relates to text comprehension and other important reading outcomes.

According to Cambria and Guthrie (2010) when talking about motivation in reading, it refers to 3 aspects: Interest, Confidence, and Dedication. Interested students read because (1) they enjoy the book, (2) being delighted by new information and (3) having a desire to achieve a reward. Confident students read because (1) they believe in their capability, (2) believe that they are a good reader and (3) believe they are better than others. Dedicated students read because (1) they believe reading is important, (2) they persist in reading assignments and (3) they attain information that expands their knowledge. Wigfield and Guthrie (1997) developed a questionnaire called the Motivation for Reading Questionnaire (MRQ) to assess these dimensions. MRQ is the instrument in collecting the data for this study because, in comparison to these other measures, the MRQ assesses a wider variety of possible dimensions of reading motivation and thus is more comprehensive than the other measures.

\section{METHOD}

Quasi-experimental research is used in this research. Two classes of the first student of Islamic senior high school was involved. One class was the experimental group and one was the control group. The experimental class was the class that 
was taught by using graphic organizer instruction. On the other hand, the control class was the class that did not use graphic organizer instruction. The population of this research was the first-year students of Islamic senior high school ArRasyid, Sungai Luar. It consists of four classes that have the same capability, A and B classes consist of 30 students, C class consists of 27 students and D class consists of 32 students. The total number of the population in MA Ar-rasyid is 119. The sampling technique was cluster sampling. The classes used in this study were selected randomly because all of the classes are homogenous. In these two sample classes, there were 26 male and 34 female students. The total numbers of the students who were taken as samples are 60.

Student's reading motivation data were obtained by using Motivation for Reading Questionnaire (MRQ) developed by Wigfield and Guthrie (1997). There are 27 items of questionnaires. The five responses used in the Likert scale include: Strongly Agree (SA),
Agree (A), Undecided (U) Disagree (D) Strongly Disagree (SD). The prequestionnaire and post- questionnaire were administered to the control group and the experimental group. The treatment was given to the experimental class by teaching the students with graphic organizer instruction while the control class did not.

\section{FINDINGS AND DISCUSSION}

Findings

This research was conducted at Islamic senior high school Arrasyid Tembilahan. The main purpose of the research was to find out the effects of graphic organizer instruction on student's reading motivation. Two classes of tenthgrade students were selected in this research as participants by using cluster random sampling. Both descriptive and inferential statistical analyses were included. Frequency counts, percentages, mean scores and standard deviation of the variables are presented in the descriptive statistical analysis. The hypotheses developed for this study are tested using an independent sample t-test and a paired-sample t-test. 
Table 1. Students' motivation result of pre-questionnaire in the experimental class

\begin{tabular}{|c|c|c|c|c|}
\hline No & Categories & Score & Frequency & Percentage (\%) \\
\hline 1 & Very High & $114-135$ & 0 & 0 \\
\hline 2 & High & $92-113$ & 0 & 0 \\
\hline 3 & Medium & $70-91$ & 0 & 0 \\
\hline 4 & Low & $48-69$ & 19 & 63.4 \\
\hline 5 & Very Low & $27-47$ & 11 & 36.6 \\
\hline \multicolumn{2}{|c|}{ Total } & 30 & 100 \\
\hline
\end{tabular}

Based on table 1, it can be seen that there are 5 categories for student participation pre-questionnaire scores of the experimental class. The frequency of Very High, High and Medium category is no student $(0 \%)$, Low category is 19 students $(63.4 \%)$, the frequency of Very Low category are 11 students $(36.6 \%)$. Thus, the majority of the students in the experimental class before being taught by using a graphic organizer instruction strategy were classified as Low.

Table 2: Students' motivation result of post-questionnaire in the experimental class

\begin{tabular}{|c|c|c|c|c|}
\hline No & Categories & Score & Frequency & Percentage (\%) \\
\hline 1 & Very high & $114-135$ & 0 & 0 \\
\hline 2 & High & $92-113$ & 13 & 43.3 \\
\hline 3 & Medium & $70-91$ & 13 & 43.3 \\
\hline 4 & Low & $48-69$ & 4 & 13.3 \\
\hline 5 & Very low & $27-47$ & 0 & 0 \\
\hline \multicolumn{2}{|c|}{ Total } & 30 & 100 \\
\hline
\end{tabular}

Based on table 2, it can be seen that there are 5 categories for student participation postquestionnaire scores of the experimental class. The frequency of Very High category is 0 students $(0 \%)$, the frequency of High category are 13 students $(43.3 \%)$, the frequency of Medium category is 13 students $(43.3 \%)$, the frequency of Low category are 4 students (13.3\%), and there is no student categorized into Very Low (0\%). The table shows that the highest percentage of student classification of student participation post-questionnaire scores of the experimental class is $43.3 \%$. Thus, the majority of the students in the experimental class after being taught by using graphic organizer instruction are classified as High and Medium. 
Table 3. Student motivation result of pre-questionnaire in control class

\begin{tabular}{|c|c|c|c|c|}
\hline No & Categories & Score & Frequency & Percentage (\%) \\
\hline 1 & Very High & $114-135$ & 0 & 0 \\
\hline 2 & High & $92-113$ & 0 & 0 \\
\hline 3 & Medium & $70-91$ & 0 & 0 \\
\hline 4 & Low & $48-69$ & 18 & 63.3 \\
\hline 5 & Very Low & $27-47$ & 12 & 36.7 \\
\hline \multicolumn{2}{|c|}{ Total } & 30 & 100 \\
\hline
\end{tabular}

Based on table 3, the 12 students $(36.7 \%)$. The table shows frequency of Very High, High, and Medium categories was no student $(0 \%)$, the frequency of Low category were 18 students $(63.3 \%)$, and the frequency of Very Low category is that the highest percentage of student motivation pre-questionnaire of the control class is $63.3 \%$. Thus, the majority of the students in the control class are classified as Low.

Table 4. Student motivation result of post-questionnaire in control class

\begin{tabular}{|c|c|c|c|c|}
\hline No & Categories & Score & Frequency & Percentage (\%) \\
\hline 1 & Very High & $114-135$ & 0 & 0 \\
\hline 2 & High & $92-113$ & 0 & 0 \\
\hline 3 & Medium & $70-91$ & 1 & 3.3 \\
\hline 4 & Low & $48-69$ & 18 & 63.3 \\
\hline 5 & Very Low & $27-47$ & 11 & 33.4 \\
\hline \multicolumn{2}{|c|}{ Total } & 30 & 100 \\
\hline
\end{tabular}

Based on table 4. The (33.4\%). The table shows that the frequency of Very High and High highest percentage of student categories is no student $(0 \%)$, the frequency of medium is 1 student motivation post-questionnaire scores of the control class is $63.3 \%$. Thus, $(3,3 \%)$ Low category is 18 students the majority of the students in the $(63.3 \%)$, and the frequency of the control class as Low.

Very Low category is 11 students

Table 5. The Analysis of Independent Sample T-test of Pre-questionnaire score between Experimental and Control Group

\begin{tabular}{|l|l|l|l|l|l|l|c|}
\hline \multicolumn{1}{|c|}{ Subject } & Research Groups & Mean & $\begin{array}{c}\text { Standard } \\
\text { Deviation }\end{array}$ & N & df & T & $\begin{array}{c}\text { Sig. (2- } \\
\text { tailed) }\end{array}$ \\
\hline $\begin{array}{l}\text { Pre- } \\
\text { questionnaire }\end{array}$ & $\begin{array}{l}\text { Experimental } \\
\text { Group }\end{array}$ & 50.03 & 9.967 & 30 & 58 & 0.026 & 0.979 \\
\hline & Control Group & 49.97 & 9.971 & 30 & & & \\
\hline
\end{tabular}


Based on an Independent Ttest analysis for the pre-questionnaire score of experimental and control groups in Table 5 above, it shows that there is no significant difference at pre- questionnaire score between experimental and control groups. The t-test result is 0.026 , its $\mathrm{df}$ is 58 , the standard deviation of the experimental group was 9.967 and the control group was 9.971. So, in the conclusion $\mathrm{p}=0.979$, the 2-tailed value is bigger than 0.05 ( $p>0.05)$. The result shows that the mean scores did not differ much between both groups. It is determined that the subjects in both groups were equivalent before giving the treatment.

Table 6. The Analysis of Independent Sample T-test of Post- questionnaire between Experimental and Control Group

\begin{tabular}{|l|l|l|l|l|l|l|l|}
\hline \multicolumn{1}{|c|}{ Subject } & Research Groups & Mean & $\begin{array}{l}\text { Standard } \\
\text { Deviation }\end{array}$ & N & df & \multicolumn{1}{|c|}{ T } & $\begin{array}{l}\text { Sig. (2- } \\
\text { tailed) }\end{array}$ \\
\hline $\begin{array}{l}\text { Post- } \\
\text { questionnaire }\end{array}$ & $\begin{array}{l}\text { Experimental } \\
\text { Group }\end{array}$ & 86.233 & 12.238 & 30 & 58 & .352 & .000 \\
\hline & Control Group & 49.966 & 9.974 & 30 & & & \\
\hline
\end{tabular}

Based on an Independent Ttest analysis for post- questionnaire score of experimental and control groups in Table 6 above, it shows that there is a significant difference in the post- questionnaire score between experimental and control groups. T-test result 0.352 , its df is 58, the standard deviation of the experimental group is 12.238 and the control group is 9.974. So, in the conclusion $\mathrm{p}=0.000$, the 2-tailed value was smaller than 0.05 $(p<0.05)$. The result showed that the mean scores did differ much between both groups. It could be determined that the subjects in both groups are not equivalent after giving the treatment. 
Table 7. The Analysis of Paired Sample T-test Between Pre-questionnaire and Post-questionnaire on students' motivation for Control Group

\begin{tabular}{|c|c|c|c|c|c|c|c|}
\hline Subject & Group Score & Mean & $\begin{array}{c}\text { Standard } \\
\text { Deviation }\end{array}$ & N & df & T & $\begin{array}{c}\text { Sig. (2- } \\
\text { tailed) }\end{array}$ \\
\hline motivation & $\begin{array}{c}\text { Pre - questionnaire } \\
\text { Score }\end{array}$ & 49.97 & 9.971 & 30 & 29 & .000 & 1.000 \\
\hline & $\begin{array}{c}\text { Post - questionnaire } \\
\text { Score }\end{array}$ & 49.97 & 9.974 & 30 & & & \\
\hline
\end{tabular}

From table 7 above, the output of the paired sample test shows that the t-test result is .000 , its df is 29 , by comparing the number of significance. If the probability $>0.05$, the null hypothesis $\left(\mathrm{H}_{01}\right)$ is rejected.
If probability $<0.05$ alternative hypothesis $\left(\mathrm{H}_{\mathrm{a} 1}\right)$ is accepted. Because the significance is $1.000>$ 0.05 , thus, $\mathrm{H}_{0}$ is accepted while $\mathrm{H}_{\mathrm{a}}$ is rejected.

Table 8. The Analysis of Paired Sample T-test Between Pre-questionnaire and Post-questionnaire on students' motivation for Experimental Group

\begin{tabular}{|l|l|l|l|l|l|l|l|}
\hline Subject & Group Score & Mean & $\begin{array}{l}\text { Standard } \\
\text { Deviation }\end{array}$ & N & df & T & $\begin{array}{l}\text { Sig.(2- } \\
\text { tailed) }\end{array}$ \\
\hline Effect & Pre - questionnaire Score & 50.03 & 9.967 & 30 & 29 & -14.149 & .000 \\
\hline & $\begin{array}{l}\text { Post - questionnaire } \\
\text { Score }\end{array}$ & 86.23 & 12.238 & 30 & & & \\
\hline
\end{tabular}

From table 8 above, the output of the paired sample test shows that the t-test result was 14.149 , its df was 29 , by comparing the number of significance. If the probability $>0.05$, the null hypothesis $\left(\mathrm{H}_{02}\right)$ is rejected. If probability $<0.05$ alternative hypothesis $\left(\mathrm{H}_{\mathrm{a} 2}\right)$ is accepted. Because the significance was $0.000<0.05$, thus, $\mathrm{H}_{\mathrm{a}}$ is accepted while $\mathrm{H}_{0}$ is rejected.

The result of data analysis is based on inferential statistics which has identified that after conducting the treatment by using graphic organizer instruction can improve $87.3 \%$ on student motivation. Therefore, the Ho hypothesis is rejected and $\mathrm{Ha}$ is accepted that there is a significant effect of graphic organizer instruction on students' reading motivation at Islamic senior high school Ar-Rasyid 


\section{Discussion}

Graphic organizer instruction allows students to create a visual image to enhance their learning (Budd, 2004) and can be used as a metacognitive tool that allows them to make connections to material in meaningful ways. Graphic organizer activities require students to actively engage in their learning, often by connecting their prior knowledge to new information. When creating a concept map, a student frequently interacts with a textbook, notes from class, an instructor, classmate, or study group. These activities will stimulate students' motivation because when constructing a concept map, students are actively engaged with cultural tools in a way that, even when a student is working alone. It can be concluded that the use of graphic organizer instruction in teaching reading not only improves reading ability reading but also improve their reading motivation.

\section{CONCLUSION}

Based on the hypothesis testing, this research proves that graphic organizer instruction can increase the students' reading motivation. the significance of this study is $0.000<0.05$, thus, $\mathrm{H}_{\mathrm{a}}$ is accepted while $\mathrm{H}_{0}$ is rejected. It means that there is an effect of Graphic organizer instruction on students' reading motivation at Islamic senior high school Ar-Rasyid.

\section{REFERENCES}

Alexander, J.E., \& Filler, R.C. (1976). Attitudes and reading. Newark, DE: International Reading Association.

Baker, L., \& Wigfield, A. (1999). Dimensions of Children's Motivation for Reading and Their Relations to Reading Activity and Reading Achievement. Reading Research Quarterly, 34, 452477.

Bromley, K., DeVitis, L. I. and Modlo, M. (1995). Graphic Organizers: Visual Strategies for Active Learning. New York: Scholastic Professional Books.

Bromley, K., DeVitis, L. I. and Modlo, M. (1999). 50 Graphic Organizers for 
Reading, Writing \& More. New York: Scholastic Professional Books.

Brown, H. (2000). Principles of language learning and teaching. New Jersey: Prentice-Hall.

Brown, H.D. (2001). Teaching by Principles: An Interactive Approach to Language Pedagogy (2nd Ed). New York: Addison Wesley Longman Inc.

Castle, Kacie. (2015) Motivation to Read: A Study of Three Primary Age Students. Education and Human Development Master's Theses.Paper 554. The College at Brockport, State University of New York

Ellis, E., \& Howard, P.W. (2007). Graphic organizers: Power tools for teaching students with learning disabilities. Current Practice Alerts, 13, 1-4.

Gardner, R. (1985). Social psychology and second language learning: the role of attitude and motivation. London: Edward Arnold.

Gardner, R. \& Lambert, W. (1972). Attitudes and motivation in second language learning. Rowley, M. A: Newbury House.
Jacobson, J. (2007). Graphic Organizers for Overhead Reading and Writing. New York: Scholastic Inc.

Lifrieri, V. (2005). A sociological perspective on motivation to learn EFL: The case of escuelas plurilingües in Argentina. M.A thesis, University of Pittsburgh.

Melekoglu, M., \& L. Wilkerson, K. (2013). Motivation to read: How does it change forstruggling readers with and without disabilities? International Journal of Instruction, 6(1), 77-88.

McKenna, M.C., Kear, D.J., \& Ellsworth, R.A. (1995). Children's attitudes toward reading: A national survey. Reading Research Quarterly, 30, 934-955.

Moreillon, J. (2007). Collaborative Strategies for Teaching Reading Comprehension. Chicago: American Library Association.

Nikolai, A. (2009). Advantages and Disadvantages of a Graphic Organizer.

http://www.ehow.com/facts 5522538_advantagesdisadvantages-graphic organizer.html

Putman, M., \& Walker, C. (2010). Motivating Children to Read and Write: Using Informal Learning Environments as Contexts for Literacy 
Instruction. Journal of

Research In Childhood

Education, 24(2), 140-151.

Renninger, K.A., Hidi, S., \& Krapp, A. (1992). The role of interest in learning and development. Hillsdale, NJ: Erlbaum.

Ryan, R.M.,\& Deci, E.L. (2000). Intrinsic and Extrinsic Motivation: Classic Definition and New Directions. Contemporary Educational Psychology, 25(1),54-67

Sharrock, T. (2008). The effect of graphic organizer on students' writing: Action Research. Kennesaw State University.

Strangman, N., Hall, T., \& Meyer, A. (2003). Graphic Organizers and Implications for Universal Design For Learning: Curriculum Enhancement Report (Cooperative Agreement No. H324H990004). Washington, DC.

Wigfield, A., \& Guthrie, J. T. (1997). Relations of children's motivation for reading to the amount and breadth of their reading. Journal of Educational Psychology, 89420-432. 